部に用ひ得ることは確かである（公差 士1〜士1.5\%）。 (山縣 清)

\section{［287］遠心分離機應用に関する諸問題}

[J.S. Pecker, Trans. A. S. M.E.*, 1939-7, Vol. 61, No 5, 頁 415 422, 図 13] 遠心分離機の隹用方面、構造、性能 及び発澾の盘勢に就て述べてある。

(画伏敬三)

［288］ピト一管による大形管流量の測定

[Edward S. Cole, E. Shaw Cole, Trans. A. S. M. E.*,
1939-8, Vol. 61, No. 6, 頁 465 475, 図 14, 表 6] 2 種 の ピトー管 (二つの測压孔が $180^{\circ}$ の方向を向いてるる所謂 Cole の ピトーメータと板の前端及び側面に孔を有するも のと）を用ひ直径 1.2 - 3.6 m の管內の流速分布を測定せる 結果を述へてるる。互に直角な二つの直径に沿うての流速を 測定し、その本均の分布曲線より（平均速度)(中心速度) の 比を求め、これが夫々の場合流量変化によつて余り影㗽を受 けす、従てこの比を求めて置けば中心速度の湘定によつて流 量測定が可能な事を述へ、塩水法との比較試驗を記してるる。 少各 ピトー管 の係数、流の方向等に就て記述してある。

（田伏敬三）

\title{
16. 機構及び機械設計
}

\section{[289］滑り片及びブラシジャを 同時に操作する機構}

[F. H. M., Machinery (E)*, 1939--7-13, Vol. 54, No.
1396, 頁 467, 図 2] 本機棈は滑り片とプランジャを同 㭙に始動させ、次に滑り片を停止させるが、プランジャは 進行を続けさせることを目的とするものである。

(長谷川一郎)

\section{7. 工作機械及びエ作法}

\section{[290］航空機用プロペラ部品の製作法}

[Machinery (E)*, 1939-6-15, Vol. 54, No. 1392, 頁 321 328, 図 16] de Havilland Aircraft Co., Ltd. に於ては 新式の 調整式プロペラの製作を行つてるる。これは 20 戋 の標準式と同様に各部品を極めて精密に仕上げることを必要 とする。文釣合を充分取ることが極めて重要である。

使用工作機械は標準型に特殊な工具を取付けて使用してる るものもあるが、中には特殊機械により連続製作を行ひつ> あるものもおる。本記事はこの加工法に就て述べてあるもの で、外側カムスリーブ座の Churchill 研磨盤による研磨仕上 特殊 Asquith 機械による カムスリーブ の孔加工、外側力 ムスリーブ穿孔用取付具、カム溝切剈用雙頭 Sundstrand 機、 內側カムスリーブ の匊切、スパイダ の腕の間の渶を加工す るブローチ 機械、ブローチ用取付具 等に就て述べてある。

(長谷川一郎)

\section{[291］リボン形材料からリンクを䡈作する方法}

[Machinery (E)*, 1939-6-15, Vol. 54, No. 1392, 賁 329,

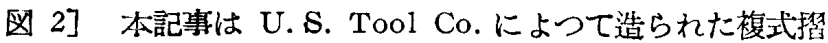
動機械により リボン形材料 から穿孔、形付け、曲げ、切取 り及び别りを連続的に行ひリンクを $1 \mathrm{mn} 340$ の割合で製 作する方法に就て述へたものである。（長谷川一郎）

\section{[292] Foden 會社工場の最近の発達}

[Machinery (E)*, 1939-6-15, Vol. 54, No. 1392, 頁 331 昭 和 14 年 12 月了
336, 図 13] 1856 年に Edwin Foden 氏によつて創立され た Fodens Ltd. は以前は蒸气機関の製作に於て名䠛を博し てるたのであるが、原動機の発達につれその後蒸气機関の慗 作はやめ ヂーゼル機関付自動車 の製作を 1931 年以春始め てるる。本記事はこの工場に於て最近設備した機械に就て述 べてあるもので、鋳物工場、熱処理工場、機峨工場、歯車の 㱔作法、東車の熱処理、粂車の研磨等に就て述へておる。

（長谷川一郎）

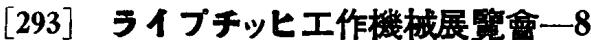

[Machinery (E)*, 1939-6-15, Vol. 54, No. 1392, 頁339 344, 図 12] 本記事に於ては，火造プレス 及ひ落下棺の特徵 を組合はした Hasenclever 製 ねぢ 式火造機械、Weingarten 製 4 クランク、圧印及び弓梴しプレス、Bauer \& Schaurte 製全自動式测定及び分類機、Hegenscheidt 製組 立車輪面の研磨盤、Prüf Union 車試驗機、Curd Nube 製重式 カム㓣り盤、Prüf-Union 製 ねぢ切部の检查裝置、 Weingarten 製肘形レバー式ギロチン形剪断機 に就て記述 してある。

(長谷川一郎)

\section{［294］ 3.7 in 高射砲用砲彈の製作法}

[Machinery (E)*, 1939-6-22, Vol. 54, No. 1393, 頁 353 382，図 45] 本記事は Machinery 記者が英国軍部の許可 により、Royal Ordnance Factory を見学し、3.7 A. A. 用㿣彈彗作法を述へたものである。記事は 3 部分に分れてを 